ORIGINAL ARTICLE

\title{
The relationship between leisure satisfaction, physical activity level and healthy life-style behaviors of sport science students during the COVID-19 pandemic
}

\author{
Ali Özkan ${ }^{\mathrm{ACDE}}$, Fatih Yaşartürk ${ }^{\mathrm{ABDE}}$, Gürkan Elçi ${ }^{\mathrm{ABC}}$ \\ Faculty of Sport Sciences, Bartin University, Turkey
}

Authors' contributions: A - Study design; B - Data collection; C - Statistical analysis; D - Manuscript Preparation; E - Funds Collection.

\begin{abstract}
Background and Study Aim

The purpose of the study was to determine the relationship between leisure satisfaction, physical activity levels and healthy life-style behaviors of sport science students during the COVID-19 pandemic in distance education.

Material and In total, 218 sport science students participated in this study voluntarily. The short form of International Methods Physical Activity Questionnaire was administered for the determination of physical activity level of distance education students. Their physical activity levels were categorized as inactive, minimally active, and physically active by using Metabolic Equivalent Term method. Health-promoting Life-style Profile Questionnaire was used with self-actualization, health responsibility, exercise, nutrition, interpersonal support, and stress management subscales. The leisure satisfaction scale was administered for the determination of leisure satisfaction.

Results: $\quad$ Results of Pearson's Product Moment Correlation Analyses indicated that there were positive significant correlations between "HLSB" and three sub-dimensions of "IPAQ" (MIA, VIA and Total). It was found positive correlation between "HLSB" and all sub-dimensions of "LSS" (Psychological, Educational, Social, Relaxation, Physiological and Aesthetical). Also, a significant positive correlation was found between four subdimensions of "LSS" (Social, Relaxation, Physiological and Aesthetical) and one sub-dimensions of "IPAQ" (W). It was observed that one sub-dimensions of "LSS" which is "Aesthetical", and a positive correlation between all sub-dimensions of "IPAQ" was found.

Conclusions: The findings of the present study indicated that healthy life-style behaviors were indicators of LSS and IPAQ and also aesthetical was found between IPAQ of sport science students.

Keywords: $\quad$ sport science students, leisure satisfaction, healthy life-style behaviors, physical activity
\end{abstract}

\section{Introduction}

In today's world, with the development of technology, the concept of time has become more important, and methods of utilizing time and the value of being effective increase every single day. Because individuals who use their time efficiently are both contended in their personal and family lives and they perform successfully at work. Therefore, the effective use of time can help students of sports science fulfill their academic and sportive responsibilities, attain the level of success that is expected of them and achieve personal satisfaction.

Higher education, within the university setting, some institutions offer only distance education, while others provide both distance and conventional education. And also distance education students physical activity levels dramatically decrease from adolescence to adulthood, as people get older. Especially, late adolescence and university years are seemed to be very critical period for the increased level of risky health behaviors such as irregular meals and sleep patterns, inactivity, bad eating habits and risk-taking behaviors like illicit drug, alcohol and tobacco use [1]. The development an individual's health may be provided by having and controlling better health status,

๑ Ali Özkan, Fatih Yaşartürk, Gürkan Elçi, 2021

doi:10.15561/20755279.2021.0501 and by reaching a fully healthy potential. In order to reach this target, the individual should keep away from violence, not smoke cigarettes, avoid communication problems with his/her family, not use drugs, control a healthy weight, and limit alcohol intake, etc. [2]. Individuals who turn such behaviours into attitudes are healthy individuals as long as they keep being healthy and aim to even improve their health status. Behaviours that are developed to be healthy may be behaviours that the individual believes in and he/ she applies in his/her life in order to remain healthy and keep away from sickness [3]. Healthy lifestyle behaviour is the control of all the behaviours and attitudes that affect health and arrangement of all the behaviours suitable for a healthy life [4]. Within this composition of behaviours, physical activity is nowadays becoming more prominent.

As it is known, immobility plays an important role in disability, and increases mortality risks. Today, it is an undeniable fact that regular physical exercise prevents or at least retards some chronic diseases [5,6]. Furthermore, for a healthy society the individual should give importance to undertaking endeavours to protect his/her health. For this reason, depending on the relationship between activity levels and health, it is important to determine the frequency, duration, intensity and type of physical activity required for a healthy lifestyle [7]. In this sense, individuals begin 
to consciously increase their physical activity, become healthier, and their leading of a healthy life increase their quality of life. If the physical activity of individuals during their studentship years become a habit, it will help them to lead a healthy life in their future life after graduation. In this sense, the students' knowledge and application of the aspects of healthy life and physical activity will give him/ her an advantage in terms of quality of life. The results obtained in our research show that in general, the average points for healthy lifestyle behaviour of the students are at medium levels. This result may be put in a "good" category for our country which is a developing one. However, the sample in our research is made up of sports science students, therefore, we can say fairly that the healthy, intellectual, and cognitive capabilities expected from university education have not been sufficiently obtained. It is observed both in the media and in research that healthy lifestyle behaviours are debated all over the world and that endeavours are made, and efforts are spent in order to turn it into a habit. If individuals want to have a healthy future or if it is their aim to increase the quality of their life, it is necessary that they should adapt these behaviours to fit their lives. Therefore, having habits of physical activity from childhood onwards, making physical exercise an essential part of one's life and at least increasing daily physical activity are all important factors with respect to maintaining one's health and decreasing the risk of health threats that individuals may face in the future.

In this sense, increasing people's awareness of their physical activity also increases the quality of life for individuals, and makes them healthier. If physical activity habits are engrained in people's lives during their school years, then this will be a foundation for a healthy life in their future years. In this sense, if students know about the aspects of a healthy lifestyle and physical activity and if they apply these factors, this will provide them with advantages in their quality of life [8]. This study which has been designed within this context will be a basis for sport science students so that they can exhibit healthy behaviours and be good role models for their athletes to ensure that society grows old healthily. In this context, in order for the individual to be healthy, exhibit a healthy life-style and increase his/her life quality, he/she should increase his/her level of physical activity. In order that the individual can lay the foundation for a healthy life, he/she should make physical activity and exercise a habit in his/ her student years at school so that this will have a lasting impact on him/her. The role of the elementary school teacher is very important in this respect, because his/ her students who are in childhood usually consider him/ her as a role model. In this sense, the fact that students perceive a healthy life-style and that they apply it in their daily lives will provide them with advantages from the viewpoint of a healthy life. Regular physical activity is a key health behavior from a public health perspective, as it has a remarkable impact on health. In respect to upper respiratory tract infection (URTI), caused by pathogens like COVID-19, physical activity may ameliorate pathological out-comes, by promoting the release of stress hormones responsible for reducing excessive local inflammation within the respiratory tract and by inducing the secretion of anti-inflammatory cytokine. Several evidences have also demonstrated that physical activity can be effective in ameliorating the mental well-being and having the potential to prevent symptoms of mental health disorder such as depression and anxiety [9].

The concept of leisure time is defined as time spent away from compulsory duties such as sleeping, working, and eating and what is important is that people spend their leisure time more efficiently with quality activities [10]. Leisure time is generally referred to in correlation with positive concepts such as happiness, entertainment, and satisfaction, and is seen as an element that can bring about a positive lifestyle [56]. Leisure activities are important as they stimulate cultural and economic development, increase work efficiency, and support education and academic competence. In other words, leisure time is when individuals feel free and can express themselves [11]. Leisure time is a very comprehensive concept associated with tourism, artistic and cultural activities, and especially physical activity $[12,13]$.

Leisure satisfaction is the positive perceptions or feelings formed as a result of engaging in leisure activities [14]. This concept is also defined as the positive emotions that individuals attain as a result of satisfying their needs through recreational activities [15]. Additionally, leisure satisfaction indicates the level of fulfillment individuals perceive from leisure activities [16]. Leisure satisfaction significantly affects an individual's perception of life satisfaction [17] and is an active component of increasing quality of life and experiencing positive feelings towards life itself [18]. The concept of leisure satisfaction can contain a wide range of variables, which is demonstrated by the fact that the demographic, socio-cultural, educational, psychological, and economic factors that influence it $[18,19]$ differ among individuals. The literature review shows that regular participation in leisure activities leads to higher satisfaction as well as multivariate improvement in individuals [20-22].

The positive correlation between leisure satisfaction and job satisfaction, motivation, quality of life, education level, and life balance $[18,23,24]$ emphasizes how important, productive, and effective leisure time activities are for the individual.

The objective of this study was to determine the relationship between leisure satisfaction, physical activity levels and healthy life-style behaviors of sport science students during the COVID-19 pandemic in distance education.

\section{Material and Methods}

\section{Participants}

In the study, two hundred eighteen male and female (male $-\mathrm{n}=128$; female $-\mathrm{n}=90$ ) students at Faculty of Sport Science in Bartın University participated voluntarily. Before data collection, the students were given information comprehensibility of the questions. Health-promoting life-style behaviors and physical 
activity data were obtained with the questionnaire form by mailing with students.

\section{Research Design}

We utilized the descriptive survey model for research purposes. Descriptive survey models are conducted on the whole population or a group or sample to make a general judgment in a population composed of many elements [57].

Data Collection Tools

The Leisure Satisfaction Scale (LSS)

The "Leisure Satisfaction Scale (LSS)" developed by Beard and Ragheb [14] now the short form, which is the form used Hawkins et al. [25]. It was adapted into Turkish by Gökçe and Orhan [26] a 5-point likert scale and the scores go from "1 - Almost never true" to "5 Almost always true". There are 24 items on the scale and 6 sub-dimensions, namely Psychological, Educational, Sociological, Physical, Relaxation, and Aesthetic. The findings of the item analysis conducted on the Turkish validity of the measurement tool confirmed the sixfactor structure of the scale. Although many methods are recommended for content validity, according to [27] the item, reliability, and validity analyses conducted following the production of the measurement tool actually prove the content validity of the tool. The internal consistency coefficient for the Turkish validity and reliability study of LSS was 0.90 for the general total, 0.77 for the psychological sub-dimension, 0.77 for the educational sub-dimension, 0.76 for the sociological subdimension, 0.80 for the relaxation sub-dimension, 0.79 for the physical sub-dimension, and 0.79 for the aesthetic sub-dimension. Since this result is between 0.60-0.80, which [28] stated as quite reliable, it means that LSS has internal consistency reliability.

Health-promoting life-style profile scale

The participants were asked to provide information about the demographic factors, such as age, gender, and education. Health-promoting Life-style Profile Scale was used for collecting data on their health behaviors. Health-promoting life-style profile scale was developed by Walker et al. [29] and composed of 48 items and 6 subscales and consists of questions about health-promoting behaviors. The subscales were on self-actualization (SA), health responsibility (HR), exercise (E), nutrition $(N)$, interpersonal support (IS), and stress management (SM). The total score reflects the healthy life-style behavior. Four more items were added to the scale, and now the scale is composed of 52 items [30]. Each respondent was asked to rate each item on likerts' 1 to 4 response scale where 1 corresponds to never, 2 sometimes, 3 often, 4 regularly. Alpha coefficient reliability of the scale was 0.92 , and alpha coefficient reliability of the subscales varied from 0.70 to 0.90 . The reliability of the scale for Turkish population was tested by Esin [4] and Akça [31]. Alpha coefficient reliability of the scale was 0.91 in Esin's study and 0.90 in Akça's study.

International Physical Activity Questionnaire (IPAQ)

IPAQ is a validated instrument to determine physical activity level of the participants [32]. IPAQ measures the frequency, duration, and level of intensity of physical activity in the last seven days across all contexts and allows for the calculation of metabolic equivalents (MET). MET presents the weekly amount of physical activity. It is a product of frequency, duration, and intensity of the physical activity performed in the last seven days. Physical activity level was measured as hours per week (MET-hours/ week) calculated according to the existing guidelines [33]. Based on the self-reported MET, frequency, and intensity of the physical activity, people can be classified into groups having low, moderate and high level of physical activity. Inactive (sedentary, low) group included the participants who reported lower than $600 \mathrm{MET}$-min/week of exercise. Minimally active (moderate level of physical activity) group included the participants who reported 601-3,000 MET-min/week of exercise, and physically active group (high, recommended level) included the participants who reported more than 3,000 MET-min/week of exercise. In this study, PA levels of the participants were evaluated through Turkish short version of IPAQ [34]. Translation and validation study of Turkish version for the university students indicated an evidence for construct validity, criterion validity (accelerometer-IPAQ short form) $(\mathrm{r}=0.30)$, and test-retest stability $(\mathrm{r}=0.69)$ [34].

\section{Statistical Analysis}

Means, standard deviations and range variability values are given as descriptive statistics, and the relationship between leisure satisfaction, healthy life-style behaviors and physical activity level was evaluated by Pearson's Product Moment Correlation Analysis. All analyzers were executed in SPSS for Windows (version 16.0) and the level of statistical significance was set at $p<0.05$.

\section{Results}

The leisure satisfaction, physical activity levels and healthy life-style behaviors of sport science students during the COVID-19 pandemic in distance education in Bartın University as assessed in this study are displayed in Table 1, 2, 3 and 4 respectively. Table 3 shows the correlations between healthy life-style behaviors and physical activity level.

Descriptive characteristics of the subjects across body composition are shown in Table 1 . Table 1 shows the average, standard deviation and range variability values of the body composition of sport science students during the COVID-19 pandemic in distance education in Bartın University. According to this table, the highest rate was reached in BMI for male and the lowest rate in female university students. Results indicated that the subjects have normal body mass index.

Table 2 indicates the average values of physical activity of the university students proved that the students had physical active group. As expected, male students had better scores when compared to the female students in all parameters listed. The mean values for physical activity were in the physically active group for both male and female students. The mean values for physical activity were in the physically active group for male but the mean values for physical activity were in the moderate level of 
Table 1. Average, standard deviation and range variability values of the body composition of the sport science students

\begin{tabular}{|c|c|c|c|c|c|c|c|c|}
\hline Participants & $\begin{array}{l}\text { Age } \\
\text { (years) }\end{array}$ & & $\begin{array}{l}\text { Body V } \\
\text { (kg) }\end{array}$ & & $\begin{array}{l}\text { Height } \\
(\mathrm{cm})\end{array}$ & & $\begin{array}{l}\text { BMI } \\
\left(\mathrm{kg} / \mathrm{m}^{2}\right.\end{array}$ & \\
\hline \multirow{2}{*}{$\begin{array}{l}\text { Sport Science } \\
\text { Students }\end{array}$} & Mean & STD & Mean & STD & Mean & STD & Mean & STD \\
\hline & 21.53 & 1.91 & 68.42 & 13.72 & 172.73 & 8.71 & 22.72 & 3.20 \\
\hline \multirow{3}{*}{$(n=218)$} & Min. & Max & Min & Max & Min & Max & Min & Max \\
\hline & 18 & 29 & 44 & 128 & 150 & 193 & 17.9 & 35.45 \\
\hline & Mean & STD & Mean & STD & Mean & STD & Mean & STD \\
\hline Male Students & 21.64 & 1.85 & 75.63 & 12.44 & 178.32 & 6.08 & 23.73 & 3.41 \\
\hline \multirow[t]{3}{*}{$(n=128)$} & Min. & Max & Min & Max & Min. & Max & Min & Max \\
\hline & 19 & 26 & 44 & 128 & 156 & 193 & 18.08 & 35.45 \\
\hline & Mean & STD & Mean & STD & Mean & STD & Mean & STD \\
\hline Female Students & 21.38 & 1.99 & 58.28 & 7.85 & 164.85 & 4.95 & 21.43 & 2.60 \\
\hline \multirow[t]{2}{*}{$(n=90)$} & Min. & Max. & Min. & Max. & Min & Max & Min & Max. \\
\hline & 18 & 27 & 45 & 78 & 150 & 176 & 17.99 & 27.30 \\
\hline
\end{tabular}

BMI: Body mass index, $\mathrm{kg}$ : kilogram, $\mathrm{cm}$ : centimetre, $\mathrm{m}^{2}$ : square meter, min: minimum, max: maximum

Table 2. Average, standard deviation and range variability values of the physical activity of the sport science students

\begin{tabular}{|c|c|c|c|c|c|c|c|c|c|}
\hline Participants & w & & MIA & & VIA & & $T$ & & $\begin{array}{l}\text { Physical } \\
\text { Activity }\end{array}$ \\
\hline \multirow{4}{*}{$\begin{array}{l}\text { Sport } \\
\text { Science } \\
\text { Students } \\
(n=218)\end{array}$} & Mean & STD & Mean & STD & Mean & STD & Mean & STD & \multirow{4}{*}{$\begin{array}{l}\text { Physically } \\
\text { Active Group } \\
\text { (3000 - >MET- } \\
\text { dk/week) }\end{array}$} \\
\hline & 899.85 & 1125.12 & 586.51 & 878.66 & 1644.22 & 1934.28 & 3130.58 & 2931.83 & \\
\hline & Min. & Max. & Min. & Max. & Min. & Max. & Min. & Max. & \\
\hline & 0 & 7276 & 0 & 3000 & 0 & 11520 & 0 & 12076 & \\
\hline \multirow{4}{*}{$\begin{array}{l}\text { Male } \\
\text { Students } \\
(n=128)\end{array}$} & Mean & STD & Mean & STD & Mean & STD & Mean & STD & \multirow{4}{*}{$\begin{array}{l}\text { Physically } \\
\text { Active Group } \\
\text { (3000 - >MET- } \\
\text { dk/week) }\end{array}$} \\
\hline & 1004.6 & 1286.7 & 641.2 & 1014.3 & 1995 & 2161.8 & 3640.9 & 3187.4 & \\
\hline & Min. & Max. & Min. & Max. & Min. & Max. & Min. & Max. & \\
\hline & 0 & 7276 & 0 & 6300 & 0 & 11520 & 0 & 12076 & \\
\hline \multirow{4}{*}{$\begin{array}{l}\text { Female } \\
\text { Students } \\
(n=90)\end{array}$} & Mean & STD & Mean & STD & Mean & STD & Mean & STD & \multirow{4}{*}{$\begin{array}{l}\text { Moderate Level } \\
\text { of Physical } \\
\text { Activity } \\
\text { (600-3000MET- } \\
\text { dk/week) }\end{array}$} \\
\hline & 750.75 & 828.00 & 509.66 & 635.37 & 1145.33 & 1422.83 & 2404.75 & 2356.50 & \\
\hline & Min. & Max. & Min. & Max. & Min. & Max. & Min. & Max. & \\
\hline & 0 & 3118 & 0 & 3000 & 0 & 7560 & 0 & 8398 & \\
\hline
\end{tabular}

W: Walking, MIA: Moderate Intensity Activity, VIA: Vigorous Intensity Activity, Total: T

physical activity group.

Table 3 shows the healthy lifestyle behaviors of the sport science students. According to this table, the highest rate was reached in self-actualization sub-scale and the lowest rate in exercise. This finding depicts the contradictory attitude of university students towards exercise.

Table 4 shows the leisure satisfaction of the sport science students. According to this table, the highest rate was reached in relaxation sub-scale and the lowest rate in aesthetic.

As seen in Table 5, Results of Pearson's Product Moment Correlation Analyses indicated that there were positive significant correlations between "HLSB" and three sub-dimensions of "IPAQ" (MIA, VIA and Total) and was positive correlation between "HLSB" and all sub-dimensions of "LSS" (Psychological, Educational, Social, Relaxation, Physiological and Aesthetical). Also, a significant positive correlation was found between four sub-dimensions of "LSS" (Social, Relaxation, Physiological and Aesthetical) and one sub-dimensions of "IPAQ" (W). At the end of this table result observed that, one sub-dimensions of "LSS" which is "Aesthtetical", a positive correlation was found between all sub-dimensions of "IPAQ".

\section{Discussion}

This study explored the relationship between leisure satisfaction, physical activity levels and healthy life-style behaviors of sport science students during the COVID-19 pandemic in distance education.

It is important to find out the relationship between physical activity and healthy life-style behavior as the results would convey the need for more efficient opportunity of physical activities in student's life. Physical activity is defined as any bodily movement produced by skeletal muscles that require energy expenditure. Physical 
Table 3. Average, standard deviation and range variability values of the healthy life style behavior of the sport science students

\begin{tabular}{|c|c|c|c|c|c|c|c|c|c|c|c|c|c|c|}
\hline \multirow{2}{*}{ 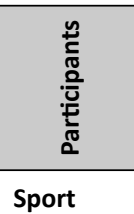 } & \multicolumn{2}{|c|}{$\begin{array}{l}\text { Self } \\
\text { Realization } \\
\text { (SR) }\end{array}$} & \multicolumn{2}{|c|}{$\begin{array}{l}\text { Health } \\
\text { Responsibility } \\
\text { (HR) }\end{array}$} & \multicolumn{2}{|c|}{$\begin{array}{l}\text { Exercise } \\
\text { (E) }\end{array}$} & \multicolumn{2}{|c|}{$\begin{array}{l}\text { Nutrition } \\
\text { (N) }\end{array}$} & \multicolumn{2}{|c|}{$\begin{array}{l}\text { Interpersonal } \\
\text { Support } \\
\text { (IS) }\end{array}$} & \multicolumn{2}{|c|}{$\begin{array}{l}\text { Stress } \\
\text { management } \\
\text { (SM) }\end{array}$} & \multicolumn{2}{|c|}{$\begin{array}{l}\text { Healthy Life } \\
\text { Style Behavior } \\
\text { (HLSB) }\end{array}$} \\
\hline & Mean & STD & Mean & STD & Mean & STD & Mean & STD & Mean & STD & Mean & STD & Mean & STD \\
\hline Science & 41.98 & 6.22 & 27.14 & 6.08 & 14.85 & 3.47 & 18.98 & 5.72 & 22.74 & 3.71 & 20.88 & 4.06 & 146.31 & 21.76 \\
\hline \multirow{3}{*}{$\begin{array}{l}\text { Students } \\
\text { ( } n=218)\end{array}$} & Min. & Max. & Min. & Max. & Min. & Max. & Min. & Max. & Min. & Max. & Min. & Max. & Min. & Max. \\
\hline & 16 & 52 & 13 & 40 & 5 & 20 & 6 & 24 & 16 & 28 & 10 & 28 & 54 & 192 \\
\hline & Mean & STD & Mean & STD & Mean & STD & Mean & STD & Mean & STD & Mean & STD & Mean & STD \\
\hline \multirow{3}{*}{$\begin{array}{l}\text { Male } \\
\text { Students } \\
(n=128)\end{array}$} & 42.69 & 6.29 & 27.67 & 6.04 & 15.46 & 3.56 & 19.64 & 6.96 & 23.32 & 3.68 & 21.67 & 3.93 & 149.98 & 22.07 \\
\hline & Min. & Max. & Min. & Max. & Min. & Max. & Min. & Max. & Min. & Max. & Min. & Max. & Min. & Max. \\
\hline & 16 & 52 & 15 & 40 & 8 & 20 & 6 & 24 & 17.9 & 28 & 14 & 28 & 54 & 192 \\
\hline \multirow{4}{*}{$\begin{array}{l}\text { Female } \\
\text { Students } \\
(n=90)\end{array}$} & Mean & STD & Mean & STD & Mean & STD & Mean & STD & Mean & STD & Mean & STD & Mean & STD \\
\hline & 40.97 & 6.00 & 26.37 & 6.10 & 14.00 & 3.46 & 18.03 & 3.02 & 21.93 & 3.61 & 19.74 & 4.00 & 141.08 & 20.30 \\
\hline & Min. & Max. & Min. & Max. & Min. & Max. & Min. & Max. & Min. & Max. & Min. & Max. & Min. & Max. \\
\hline & 28 & 51 & 13 & 40 & 5 & 20 & 12 & 24 & 16 & 28 & 10 & 27 & 82 & 190 \\
\hline
\end{tabular}

Table 4. Average, standard deviation and range variability values of the Leisure Satisfaction Scale (LSS) of the sport science students

\begin{tabular}{|c|c|c|c|c|c|c|c|c|c|c|c|c|c|c|}
\hline \multirow{2}{*}{ 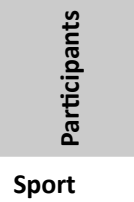 } & \multicolumn{2}{|c|}{$\begin{array}{l}\text { Psychological } \\
\text { (PSY) }\end{array}$} & \multicolumn{2}{|c|}{$\begin{array}{l}\text { Educational } \\
\text { (EDU) }\end{array}$} & \multicolumn{2}{|l|}{$\begin{array}{l}\text { Social } \\
\text { (SOC) }\end{array}$} & \multicolumn{2}{|c|}{$\begin{array}{l}\text { Relaxation } \\
\text { (REL) }\end{array}$} & \multicolumn{2}{|c|}{$\begin{array}{l}\text { Physiology } \\
\text { (PHY) }\end{array}$} & \multicolumn{2}{|c|}{$\begin{array}{l}\text { Aesthetic } \\
\text { (AES) }\end{array}$} & \multicolumn{2}{|c|}{$\begin{array}{l}\text { Leisure } \\
\text { Satisfaction } \\
\text { Scale (LSS) }\end{array}$} \\
\hline & Mean & STD & Mean & STD & Mean & STD & Mean & STD & Mean & STD & Mean & STD & Mean & STD \\
\hline \multirow{4}{*}{$\begin{array}{l}\text { Students } \\
(n=218)\end{array}$} & 3.65 & 0.80 & 3.87 & 0.82 & 3.75 & 0.78 & 3.97 & 0.78 & 3.62 & 0.78 & 3.62 & 0.77 & 3,74 & 0.78 \\
\hline & Min. & Max. & Min. & Max. & Min. & Max. & Min. & Max. & Min. & Max. & Min. & Max. & Min. & Max. \\
\hline & 1 & 5 & 1 & 5 & 1 & 5 & 1 & 5 & 1 & 5 & 1 & 5 & 1 & 5 \\
\hline & Mean & STD & Mean & STD & Mean & STD & Mean & STD & Mean & STD & Mean & STD & Mean & STD \\
\hline \multirow{3}{*}{$\begin{array}{l}\text { Male } \\
\text { Students } \\
(n=128)\end{array}$} & 3.66 & 0.88 & 3.93 & 0.86 & 3.81 & 0.85 & 3.94 & 0.84 & 3.65 & 0.81 & 3.65 & 0.81 & 3.77 & 0.84 \\
\hline & Min. & Max. & Min. & Max. & Min. & Max. & Min. & Max. & Min. & Max. & Min. & Max. & Min. & Max. \\
\hline & 1 & 5 & 1 & 5 & 1 & 5 & 1 & 5 & 1 & 5 & 1 & 5 & 1 & 5 \\
\hline \multirow{4}{*}{$\begin{array}{l}\text { Female } \\
\text { Students } \\
(n=90)\end{array}$} & Mean & STD & Mean & STD & Mean & STD & Mean & STD & Mean & STD & Mean & STD & Mean & STD \\
\hline & 3.64 & 0.69 & 3.80 & 0.74 & 3.66 & 0.67 & 4.01 & 0.69 & 3.59 & 0.75 & 3.57 & 0.65 & 3.75 & 0.69 \\
\hline & Min. & Max. & Min. & Max. & Min. & Max. & Min. & Max. & Min. & Max. & Min. & Max. & Min. & Max. \\
\hline & 1 & 2.5 & 2 & 5 & 2 & 5 & 2.5 & 5 & 1.25 & 5 & 2.5 & 5 & 1 & 5 \\
\hline
\end{tabular}

Table 5. The relationship between leisure satisfaction, physical activity levels and healthy life-style behaviors of sport science students

\begin{tabular}{llllllllllll}
\hline Variables & PSY & EDU & SOC & REL & PHY & AES & LSS & W & MIA & VIA & T \\
\hline SR & $.307^{* *}$ & $.338^{* *}$ & $.372^{* *}$ & $.358^{* *}$ & $.257^{* *}$ & $.395^{* *}$ & $.397^{* *}$ & $.140^{*}$ & $.210^{* *}$ & $.294^{* *}$ & $.310^{* *}$ \\
HR & $.150^{*}$ & $.192^{* *}$ & $.195^{* *}$ & $.137^{*}$ & $.209^{* *}$ & $.240^{* *}$ & $.220^{* *}$ & -.025 & $.186^{* *}$ & $.216^{* *}$ & $.189^{* *}$ \\
\hline E & $.226^{* *}$ & $.264^{* *}$ & $.288^{* *}$ & $.268^{* *}$ & $.400^{* *}$ & $.290^{* *}$ & $.340^{* *}$ & .116 & $.266^{* *}$ & $.321^{* *}$ & $.336^{* *}$ \\
N & $.142^{*}$ & $.168^{*}$ & $.159^{*}$ & .120 & $.196^{* *}$ & $.168^{*}$ & $.187^{* *}$ & .069 & .087 & $.163^{*}$ & $.160^{*}$ \\
IS & $.334^{* *}$ & $.321^{* *}$ & $.418^{* *}$ & $.336^{* *}$ & $.364^{* *}$ & $.413^{* *}$ & $.428^{* *}$ & .123 & .129 & $.202^{* *}$ & $.219^{* *}$ \\
SM & $.272^{* *}$ & $.283^{* *}$ & $.284^{* *}$ & $.270^{* *}$ & $.202^{* *}$ & $.289^{* *}$ & $.314^{* *}$ & .103 & $.209^{* *}$ & $.270^{* *}$ & $.281^{* *}$ \\
HLSB & $.310^{* *}$ & $.342^{* *}$ & $.373^{* *}$ & $.327^{* *}$ & $.341^{* *}$ & $.393^{* *}$ & $.409^{* *}$ & .104 & $.248^{* *}$ & $.325^{* *}$ & $.328^{* *}$ \\
W & .102 & .126 & $.140^{*}$ & $.138^{*}$ & $.149^{*}$ & $.141^{*}$ & $.156^{*}$ & 1 & $.222^{* *}$ & $.273^{* *}$ & $.630^{* *}$ \\
MIA & .078 & .095 & .115 & .105 & .102 & $.211^{* *}$ & $.138^{*}$ & $.222^{* *}$ & 1 & $.350^{* *}$ & $.616^{* *}$ \\
VIA & -.025 & .006 & -.001 & .027 & .079 & $.176^{* *}$ & .050 & $.273^{* *}$ & $.350^{* *}$ & 1 & $.869 * *$ \\
T & .046 & .081 & .088 & .102 & $.140^{*}$ & $.233^{* *}$ & $.134^{*}$ & $.630^{* *}$ & $.616^{* *}$ & $.869 * *$ & 1 \\
\hline
\end{tabular}

${ }^{*} \mathrm{p}<0.05 ;{ }^{* *} \mathrm{p}<0.01 ;$ PSY - Psychological; EDU - Educational; SOC - Social; REL - Relaxation; PHY - Physiology; AES Aesthetic; LSS - Leisure Satisfaction Scale. 
inactivity (lack of physical activity) has been identified as the fourth leading risk factor for global mortality $(6 \%$ of deaths globally). Regular physical activity and exercise help improve physical fitness (aerobic fitness, muscular fitness, flexibility, and body composition) of individuals and, therefore, promote a healthy life-style [35]. Also, regular physical activity and exercise help improve physical fitness of individuals, thus promoting a healthy life-style.

Sedentary life-style leads to a greater risk of developing coronary heart disease, hypertension, high blood lipid profile, type 2 diabetes, obesity, and some forms of cancer, like colon and breast cancer. Many studies reported that engaging in physical activity and exercise on regular basis lowers blood pressure, improves lipoprotein profile, C-reactive protein, and other CHD biomarkers, enhances insulin sensitivity, and plays an important role in weight management [36-38]. On the other hand, physical inactivity and lack of exercise result in many problems including threatening or limiting a healthy life. Although some students were found to be a similar physically active, but body fat percentage were high due to their diet. Body fat percentage can differ according to age, nutrition, race, environmental factors and gender. On the other hand, health and physical fitness improves quality of life. It is known fact that modern technology results in a sedentary lifestyle $[39,40]$.

The present study depicted that distance education sport science students in Bartın University are physically active group in terms of physical activity level and have an average score in healthy life-style behaviors and leisure satisfaction. But Özkan [41] found that distance education students in Hoca Ahmet Yesevi University are minimally active in terms of physical activity level and have an average score in healthy life-style behaviors. Türkmen et al. [42] and Çelik et al. [43] reached to similar findings in their researches, which were carried on students in Çanakkale 18 Mart University and Bartın University in Turkey. Besides another study which focused on the university students' physical activity levels found that $50 \%$ of them were inactive or exercising below the recommended level [44]. In another study carried out in Turkey, Nacar et al. [45], found that even the Sports High Schools do not have sufficient sport facilities for the students. Therefore, it is difficult to expect the students to have awareness of healthy lifestyle behaviors without the existence of necessary conditions [41].

Although the LSS total score and total score averages of all sub-dimensions were close according to the gender variable, the results proved to be in favor of the male participants. Studies conducted by Acar and Yilmaz [46] on the leisure satisfaction of university students, by Aydın and Yaşartürk [47] on elite athletes studying at university, by Serdar and Demirel [48], on sports science students, by Uluç, Duman, and Acar [49], with university students, by Yaşartürk [50] on sports science students, and by Yaşartürk and Bilgin [51], on university students competing in handball are in line with this study. According to the gender variable, the average scores of men in LSS and its subdimensions were higher than that of women. Additionally, when Doğan, Elçi, and Gürbüz [52] examined the average scores according to the gender variable in their study, they found that women got higher scores in educational and physical sub-dimensions, while men got higher scores in psychological, sociological, relaxation, and aesthetic subdimensions. In a study conducted on physical education and sports teaching students Erdemli and Yaşartürk [53] examined the average scores according to the gender variable and reported that results were in favor of women in the psychological and physical sub-dimensions and in favor of men in the education, sociological, relaxation, and aesthetic sub-dimensions. Cengiz and Yaşartürk [54] examined the average scores according to the gender variable in their study on fitness participants and found that women got higher scores in the physical and sociological sub-dimensions, and men in the psychological, education, relaxation, and aesthetic sub-dimensions. Hadi, Erdem, and Duman [55] did not find a significant difference between individuals participating in recreational sports activities in terms of gender variables in LSS and its sub-dimensions. Results of other studies in the literature present similarities with our study, which shows that men attain more satisfaction than women as a result of leisure activities. The findings show that leisure activities significantly affect participants and leisure satisfaction will increase as the frequency of participation in such activities increases.

\section{Conclusions}

In conclusion the satisfaction sports science students attain from leisure activities will improve academic selfefficacy through individual and active participation, make students more mentally resistant during the COVID-19 pandemic and increase their motivation for education and healthy living.

\section{Recommendations}

Sports science students are recommended to do mental activities as well as physical activities, in order to develop healthy lifestyle habits during the pandemic period, as it will help them become less vulnerable to COVID-19.

During the pandemic, doing physical activities at home will be just as productive, therefore, sports science students are recommended not to disregard the importance of being active.

The satisfaction sports science students acquire from leisure activities will improve their living standards and it is recommended that they undertake various activities that will increase their motivation, particularly during the pandemic.

\section{Acknowledgements}

This study was written by abridging Ali Özkan, Fatih Yaşartürk, Gürkan Elçi. No grants or financial aids were taken in this Project.

\section{Financial support}

There is no financial support.

\section{Conflict of interest}

The authors report no conflict of interest. 


\section{References}

1. Z. Health promoting behaviors and exercise stages of change levels of students at transition to university. Ankara: Middle East Technical University Social Sciences Institute; 2007.

2. Çimen S. Developing "health risk behaviours scale" in adolescents between 15 and 18 years old. Istanbul: Istanbul University; 2003.

3. Yalçınkaya M, Özer FG, Karamanoğlu AY. Evaluation of healthy lifestyle behaviors in health care workers. TAF Preventive Medicine Bulletin, 2007; 6: 409-20.

4. Esin MN. Evaluation and promotion of health behaviors of industry workers. Istanbul: Istanbul University Health Science Institute; 1997.

5. Pate RR, Pratt M, Blair SN, Haskell WL, Macera CA, Bouchard C, King AC. Physical activity and public health: a recommendation from the centers for disease control and prevention and the american college of sports medicine. JAMA, 1995; 273(5): 402- 407. https://doi.org/10.1001/jama.1995.03520290054029

6. Pitta F, Troosters T, Probst V, Spruit M, Decramer M, Gosselink R. Quantifying physical activity in daily life with questionnaires and motion sensors in COPD. European Respiratory Journal, 2006; 27(5): 1040- 407. https://doi.org/10.1001/jama.1995.03520290054029

7. Montoye HJ. Introduction: evaluation of some measurements of physical activity and energy expenditure. Medicine \& Science in Sports \& Exercise, 2000; 32(9): 439- 441. https://doi.org/10.1097/00005768-200009001-00001

8. Bozkuş T, Türkmen M, Kul M, Özkan A, Öz Ü, Cengiz C. Determination and relationships of physical activity level and healthy lifestyle behaviors in physical education students. International Journal of Science Culture and Sport (IntJSCS), 2013; 1(3): 49-65.

9. Maugeri G, Castrogiovanni P, Battaglia G, Pippi R, D'Agata V, Palma A, Musumeci G. The impact of physical activity on psychological health during Covid-19 pandemic in Italy. Heliyon, 2020; 6(6): 15- 25. https://doi.org/10.1016/j.heliyon.2020.e04315

10.Gürbüz B, Karaküçük S. Leisure Constraints Scale-28: scale development, validity and reliability study, Gazi Journal of Physical Education and Sport Sciences, 2007; 12(1): 3-10.

11.Henderson KA, Bialeschki MD. Leisure and active lifestyles: research reflections. Leisure Sciences, 2007; 27(5): 355-365. https://doi.org/10.1080/01490400500225559

12.Aitchison C. Gender and leisure: social and culturel perspectives. London: Routledge; 2003.

13.Gürbüz B. The conception and perception of leisure in Turkey. Champaign, IL, Sagamore Publishing: Henderson K \& Sivan A; 2017.

14.Beard JG, Ragheb MG. Measuring leisure satisfaction. Journal of Leisure Research, 1980; 12(1): 20- 33. https://doi.org/10.1080/00222216.1980.11969416

15.Siegenthaler KL, O'Dell I. Meeting the leisure needs of families. Journal of Parks and Recreation, 1998; 33(12): 38-43.

16.Du Cap MC. The perceived impact of the acadia advantage program on the leisure lifestyle and leisure satisfation of the students at Acadia University. Ottowa: Acadia University; 2002.

17.Wang EST, Chen LSL, Lin JYC, Wang MCH. The relationship between leisure satisfaction and life satisfaction of adolescents concerning online games. Adolescence, 2008; 43(169): 177-184.

18.Siegenthaler KL, O’Dell I. Leisure attitude, leisure satisfaction, and perceived freedom in leisure within family dyads. Leisure Sciences, 2000; 22(4): 281- 296. https://doi.org/10.1080/01490409950202302

19.Iso-Ahola SE, Weissinger E. Perceptions of boredom in leisure: conceptualization, reliability, and validity of the leisure boredomscale. JournalofLeisureResearch, 1990;22(1):1-17. https://doi.org/10.1080/00222216.1990.11969811

20.Choi S, Yoo, Y. Leisure attitude and satisfaction with leisure and life: proposing leisure prioritization and justification, World Leisure Journal, 2017; 59(2): 140- 155. https://doi.org/10.1080/16078055.2016.1216886

21.Lee B, Zhang A. Women's leisure and leisure satisfaction in contemporary urban China. World Leisure Journal, 2010; 52(3): 211- 221. https://doi.org/10.1080/04419057.2010.9728284

22.Hribernik J, Mussap AJ. Leisure satisfaction and subjective wellbeing. Annals of Leisure Research, 2010; 13(4): 701-708. https://doi.org/10.1080/11745398.2010.9686871

23.Pearson QM. Job satisfaction, leisure satisfaction, and psychological health. The Career Development Quarterly, 1998; 46(4): 416- 426. https://doi.org/10.1002/j.2161-0045.1998.tb00718.x

24.Beard JG, Ragheb MG. Measuring leisure interests, Journal of Park and Recreation Administration, 1992; 10(2): 1-13.

25.Hawkins BA, Ardovino P, Rogers NB, Foose A, Olsen N. Leisure assessment inventory. Ravensdale, WA: Idyll Arbor; 2002.

26.Gökçe H, Orhan K. Validity and reliability study of the leisure satisfaction scale (LSS) into Turkish, Hacettepe Journal of Sport Sciences, 2011; 22(4): 139-145.

27.Erkuș A. Bilimsel araștırma sarmalı [Scientific research spiral]. 7th ed. Ankara: Seçkin Bookstore; 2021 (In Turkish).

28.Alpar R. Spor bilimlerinde uygulamall istatistik [Applied statistics in sports sciences]. Ankara: Nobel Bookstore; 2001 (In Turkish).

29.Walker SN, Sechrist KR, Pender NJ. Health promotion life-style profile development psychometrics. Nursing Research, 1987; 36: 76- 80. https://doi.org/10.1097/00006199-198703000-00002

30.Walker SN, Hill-Polerecky DM. Psychometric evaluation of the health promotion life-style profile. Lincoln: University of Nebraska Medical Center; 1987.

31.Akça S. Evaluation of health behaviors among lecturers and of affecting factors. İzmir: Ege University Health Science Institute; 1998.

32.Craig CA, Marshall AL, Sjostrom M, Bauman AE, Booth ML, Ainsworth BE, Pratt M, Ekelund U, Yngve A, Sallis JF, Oja P. International physical activity questionnaire: 12-country reliability and validity. Medicine Science Sports Exercise, 2003; 35(8): 1381- 1395. https://doi.org/10.1249/01.MSS.0000078924.61453.FB

33.IPAQ research committee Guidelines for data processing and analysis of International Physical Activity Questionnaire [online], Retrieved on 5 August 2020 [cited by 2021 Feb 15] Available from: http://www.ipaq.ki.se.

34.Öztürk M. A researchon reliability and validity of international physical activity questionnaire and determination of physical activity level in university students. Ankara: Hacettepe University Health Science Institute; 2005.

35.Özkan A, Köklü Y, Kayıhan G, Alemdaroğlu U, Ersöz G. The role of physical activity and exercise in prevention and treatment of obesity. SSTB International Refereed Academic Journal of Sports, Health and Medical Sciences, 2013; 3(7): 48-63.

36.Ay S, Yanıkkerem E, Çalım SI, Yazıcı M. Health-promoting lifestyle behavior for cancer prevention: a survey of 
turkish university students. APJCP, 2012; 13: 2269- 2277. https://doi.org/10.7314/APJCP.2012.13.5.2269

37.Knechtle B. Influence of physical activity on mental well-being and psychiatric disorders. Schweizerische Rundschau fur Medizin Praxis, 2004; 93(35): 1403- 1411. https://doi.org/10.1024/0369-8394.93.35.1403

38. Macauley E. Physical Activity and Psychosocial Outcomes. Champagne, Illinois, Human Kinetics: Bouchard C; 1994.

39. Orhan S. The realitonship between physical activity level, body mass index, and body fat percentage in urban and rural elemantry school students. Education Research Review, 2015; 10(1): 69- 74. https://doi.org/10.5897/ERR2014.1916

40.Finn K, Johansen N, Specker B. Factors associated with physical activity in perp school children. Journal of Pediatri, 2002; 140: 81- 85. https://doi.org/10.1067/mpd.2002.120693

41.Özkan A. The relationship between physical activity levels and healthy lifestyle behaviors of distance education students. Educational Research and Reviews, 2015; 10(4): 416- 422. https://doi.org/10.5897/ERR2015.2082

42.Türkmen M. The relationships between gender, physical self-perception, sport experience, motivation orientations and academic success. International Journal of Academic Research Part B, 2013; 5(5): 10- 16. https://doi.org/10.7813/2075-4124.2013/5-5/B.10

43.Çelik GO, Malak AT, Bektaş M, Yılmaz D, Yümer AS, Öztürk Z, Demir E. Examination of factors affecting health school student's health promotion behavior. Anatolian Journal of Clinical Investigation, 2009; 3(3): 164-169.

44.Savcı S, Öztürk M, Arıkan H, İnal İnce D, Tokgözoğlu L. Physical activity levels of university students. Archives of the Turkish Society of Cardiology, 2006; 34(3): 166-172.

45.Nacar E, Gacar A, Karahüseyinoğlu MF, Gündoğdu C. Analysis for sports facilities in sports high school in terms of quality and quantity (central anatolia region sample). Australian Journal of Basic and Applied Sciences, 2013; 7(2): 627-631.

46.Acar K, Y1lmaz AK. The relationship between university students' leisure satisfaction and life satisfaction. Physical Education and Sport Sciences Journal, 2021; 15(1): 25-35.

47.Aydın O, Yaşartürk F. Investigation of the relationship between satisfaction and self perception levels of recreational activities of elite level bocce athletes studying in university. MANAS Journal of Social Studies, 2021; 9(1): 449- 461. https://doi.org/10.33206/mjss.541627

48.Serdar E, Demirel M. The relationship between perceived stress and leisure satisfaction: example of sports sciences students. Journal of Physical Education and Sport Sciences, 2020; 22(3): 54-64.

49.Uluç E, Duman S, Acar H. Examining the impact of free time saturation levels on life saturation of international students studying at the university. Mediterranean Journal of Sport Science, 2020; 3(2): 407-419.

50.Yaşartürk F. Analysis of the relationship between the academic self-efficacy and leisure satisfaction levels of university students. Journal of Education and Training Studies, 2019; 7(3): 106- 115. https://doi.org/10.11114/jets.v7i3.3988

51.Yaşartürk F, Bilgin B. Investigation of free time satisfaction and life satisfaction levels of handball studying in university. International Journal of Contemporary Educational Studies (IntJCES), 2018; 4(2): 50-60.

52.Doğan M, Elçi G, Gürbüz B. Examination of relationship between leisure satisfaction, leisure boredom and job satisfaction: a research on academicans. The Journal of Physical Education and Sport Sciences, 2019; 17(1): 154164.

53.Erdemli E, Yaşartürk F. Examination of the relationship between free time satisfaction level and problem solving skills of physical education and sports teacher department students. MANAS Journal of Social Studies, 2020; 9(3): 1871- 1882. https://doi.org/10.33206/mjss.605808

54.Cengiz R, Yaşartürk F. Examination of the relationship between fitness participants' service quality and leisure satisfaction levels in gyms. International Journal of Contemporary Educational Studies (IntJCES), 2020; 6(1): 48-62.

55.Hadi G, Erdem B, Duman E. Investigation of the relationship between leisure time satisfaction levels and dispositional flow states of recreational sports' participants. Hacettepe Journal of Sport Sciences, 2021; 32(1): 10-19.

56.Stebbins RA. The idea of leisure. 1st ed. New York: Transaction Publishers; 2011.

57.Karasar N. Bilimsel araştırma yöntemi [Scientific research method]. Ankara: Nobel Academic Publishing; 2017 (In Turkish).

\section{Information about the authors:}

Ali Özkan; https://orcid.org/0000-0002-2859-2824; ali_ozkan1@hotmail.com; Bartin University, Bartın, Turkey.

Fatih Yaşartürk; (Corresponding author); https://orcid.org/0000-0003-4934-101X; fatihyasarturk@gmail.com; Bartin University; Bartın, Turkey.

Gürkan Elçi; https://orcid.org/0000-0002-8889-9692; gelci@bartin.edu.tr; Bartin University; Bartın, Turkey.

\section{Cite this article as:}

Özkan A, Yaşartürk F, Elçi G. The relationship between leisure satisfaction, physical activity level and healthy life-style behaviors of sport science students during the COVID-19 pandemic. Physical Education of Students, 2021;25(5):257-264. https://doi.org/10.15561/20755279.2021.0501

This is an Open Access article distributed under the terms of the Creative Commons Attribution License, which permits unrestricted use, distribution, and reproduction in any medium, provided the original work is properly cited http://creativecommons.org/licenses/by/4.0/deed.en 